\title{
Behaviours of the Effective Leadership in Universities: Findings of a Meta- Analysis Study
}

\author{
Burhanuddin \\ Department of Educational Administration, State University of Malang, Indonesia \\ burhanuddin.fip@um.ac.id
}

\begin{abstract}
The purposes of this study are to investigate what sorts of leadership behaviours, and how leaders contribute to the successful universities in many countries. The investigation was accomplished using a simple meta-analysis model. Based on several research studies and literature reviews, the findings indicated a range of leadership styles have been applied in many universities in Europe U.S., and Asia. The effective leadership behaviours for the global context, however, were dominantly found in universities lead under transformational process. This style is practiced since it fits to deal with the changing and competitive environment. The executives, thus, have to be furnished with reputable competencies to implement this model. Future studies are suggested to concern more on personality traits as they are key elements in developing the individual leadership capacities.
\end{abstract}

Keywords: leadership behaviour, university, transformational, effective, organization

\section{INTRODUCTION}

Higher education system has grown rapidly [1, 2] and involved in dynamics around the world competition [3, 4]. Government and society expand the efforts in this sector to help people lift up their quality of life benefiting from this education level [1,3]. Results of the global research found that the graduates from higher education system as well as universities earn rate returns higher than those from other school levels. However, although many achievements obtained by the sector, great works remain to challenge this sector. These include leading to enhance learning achievements, promoting and expanding equitable access, education relevance, strengthening the transfer of knowledge and technology to the coming generations, and encouraging desired behaviours, attitudes, and values [1, 3].

Those enactments are significantly influenced by higher institutions performance, the diverse program alternatives, relevant, equitable and efficient higher education system. Furthermore, research is the key product to enhance the quality of life in terms of community economic growth. To enable higher education institutions specifically universities as the focus of this study to lift their performance at higher levels, the tertiary organizations have to be lead in ways within which their human resources are ideally empowered [5]. What sorts of leadership behaviours, and how leaders contribute to the successful universities are sought in this article. This purpose is accomplished through a research employing a simple meta-analysis model.

\section{Why University Leadership Matters}

The provision of leadership in university organizations has attracted most societies in the world. The reasons are that the ways of higher education institutions to be led have consequences on their performance in promoting young people to better lives, and contributing to the public [6]. Having opportunities at this education level provides students with abilities to enhance their potential as well as individual independence and initiatives - both are valuable elements for living in this global environment. Education products also have macro-economic impacts on human investment programs in obtaining successful life in labour markets. Thus, it constitutes the future society and family profile in terms of higher economic earning [7].

However, while globalization of economic, geographic, technological changes influenced the performance of higher education system, these factors have not been successfully incorporated by some countries especially in the world [6,7]. Educational systems and the programs of higher education institutions seemingly failed to respond the demands of the existing global issues. Students are not well educated to obtain basic life skills and managerial capacities in order to be survive in this competitive global environment [8].

Graduates of the universities, then, do not have higher individual capacities in contributing to the social and economic growth of the country and the society. Leadership of this sector is thus, undoubtedly challenged as one of the strategic requirement for developing university performance specifically in this article is focused on university leaders that have capacities in managing university organizations within turbulent global factors [1,9].

\section{Leadership Theories Underpinning the Effective University Leadership \\ Many leadership theories have been develop} including trait, behavioural, and situational or contingency approaches. Studies underpinned by these theories were carried out to explore effective leadership behaviours in responding to the demands of organizations. The reasons are that leadership power is predicted to have strong influences on how people work in accomplishing organizational objectives. In particular, the performance of a university as an organization is considerably determined by leadership behaviours implemented in the sector. It is evidence that at most universities, the successful management of organizational matters as well as educational planning, faculty appointments, curriculum developments, and staff promotions are effected strongly by the ways how university executives work to lead their people within the university organizations $[9,10]$. 


\section{University Leadership Behaviours}

Higher education as a system requires particular approaches to manage[4]. These may emerge as how leaders use their power in implementing a range of leadership models from autocratic to democratic styles [11-13]. Under which circumstances, leadership is exercised from providing more freedom for followers to limiting access for these people $[9,14]$. On behalf of the magnitude of human empowerment, leaders as well as university executives might choose certain behaviours ranging from directive to participative and delegation. The effective use of these models depend on the maturity level of the subordinates led in organizations [13, 15]. Contemporary leadership behaviours have been identified in many literatures and studies. Some of these include transformational, transactional, and charismatic leadership [11, 14]. Organizational leaders as well as university executives who use a transformational approach inspire their followers to work a high valued vision and work for the best enthusiastically [14]. These subordinates demonstrate loyalty, respect their leaders, have trust, appreciation, and highly motivated in undertaking the tasks with extra targets [11]. Contrarily, transactional is not based on personal commitment and enthusiasm. Rather, it is practiced through a transaction between leaders and followers, the exchange of followers submissions with leaders' request [11]. People who completed their tasks usually would get rewards from their boss [14]. Almost similar with transformational, subordinates led under a charismatic leadership model work with fully inspired, committed, and demonstrating high excitement, and optimism. These subordinates are also highly motivated to accomplish the jobs in pursuing the vision compelling vision developed by leaders $[11,16]$.

The discussions in the next passages are based on university organization contexts not a college as a case. The reasons are that compared to other types of organizations, a university organization has different characteristics [4]. This article only focuses only one of the most important components in describing these characteristics, the human factor. This choice is based on a university setting where its leaders work with various people whose certain levels of expertise and professions. Various jobs are assigned to the persons having different qualities, qualifications and competencies. These jobs would require special skills and expertise. University staff members must have sufficient knowledge, skills, and expertise in implementing university's organizational programs.
They are led to foster develop academic culture through research and experiments [17, 18]. While, other public organizations do not demand the same systems or works that are designed in the university governance. Jobs in the public enterprises are identified as more routine, bureaucratic, strict, and static.

Finally, the assessment of higher education performance requires a comprehensive understanding on global dimensions that relate mostly to the trend of its development across countries. The old assumption that perceived higher education is comprised by relatively national systems is no longer relevant to be used as an appropriate way of higher education comparisons in the world. Inter-dependency of nations and universities around the world challenges universities. This trend is driven by advanced formation technology, and global data transformations from societies and individuals. In order to be able to cope with this dynamic environment, leadership behaviours in those tertiary institutions must extend themselves beyond the territorial limits of government authorities.

\section{METHODS}

The current study uses a metaanalysis technique that integrates multiple scientific findings of studies. The basic assumption of this procedure is that there is a common truth generated from relevant studies where a certain error of the respective studies is estimated. To derive the pooled estimates that are close to unknown common truth, certain statistics approaches were used. Meta-analysis is able to compare results from some studies, identify patterns of findings among the studies, differences, sources of those results, and relationships that come up from the multiple studies [19]. The subjects included in this study were studies from articles, book chapters, and other related published works. The major requirements for inclusion were quantitative data from statistical analyses and some qualitative studies reported in published works including journals, books, proceedings, or other scientific results.

\section{RESULT}

Findings from this meta-analysis study is summarized in the following (Table 1). Results show universities in many countries employed various leadership behaviours. Evidences from studies by Anyamele in Finland, 2005 reported that universities have used many kinds of leadership styles [20].

Table 1

Summary of the Research Findings

\begin{tabular}{|c|l|l|l|l|}
\hline No & \multicolumn{1}{|c|}{ Sources } & \multicolumn{1}{c|}{$\begin{array}{c}\text { Method / Research Design / } \\
\text { Technique }\end{array}$} & \multicolumn{1}{c|}{ Variable / Subvariable } & \multicolumn{1}{c|}{ Findings: Leadership Behaviors } \\
\hline 1 & $\begin{array}{l}\text { Sadeghi \& } \\
\text { Pihie, 2012. }\end{array}$ & $\begin{array}{l}\text { Quantitative study using survey } \\
\text { questionnaire of MLQ (Multi Factor } \\
\text { Leadership Questionnaire), involving } \\
\text { 298 participants of lecturers in three } \\
\text { Research Universities in Malaysia. }\end{array}$ & $\begin{array}{l}\text { Leadership styles as applied by heads } \\
\text { of departments at the schools, and its } \\
\text { effectiveness. }\end{array}$ & $\begin{array}{l}\text { Results indicate that leaders of the } \\
\text { departments employed leadership } \\
\text { behaviors formed from a combination } \\
\text { of three models including free-rein, } \\
\text { transformational, and transactional. } \\
\text { The variance explained was } 82 \% \\
\text { suggesting the effective leadership } \\
\text { process implemented in the } \\
\text { departments. }\end{array}$ \\
& & & \\
\end{tabular}




\begin{tabular}{|c|c|c|c|c|}
\hline No & Sources & $\begin{array}{c}\text { Method / Research Design / } \\
\text { Technique }\end{array}$ & Variable / Subvariable & Findings: Leadership Behaviors \\
\hline & & & & $\begin{array}{l}\text { The findings were also supported by } \\
\text { further results of regression analysis } \\
\text { model showing leader attributes, } \\
\text { motivation, reward, members' } \\
\text { consideration, laissez-faire style, } \\
\text { management, and intellectual } \\
\text { encouragement were found as } \\
\text { significant predictors of this } \\
\text { successful leadership behaviors. }\end{array}$ \\
\hline 1 & $\begin{array}{l}\text { Bodla \& } \\
\text { Nawaz, } 2010 .\end{array}$ & $\begin{array}{l}\text { Quantitative approach employing } \\
\text { Multi Factor Leadership } \\
\text { Questionnaire that were administered } \\
\text { to } 265 \text { faculty members as participants } \\
\text { of Universities in Pakistan. }\end{array}$ & $\begin{array}{l}\text { Leadership style practiced at the } \\
\text { schools or faculties focusing on the } \\
\text { selected models of leadership as well } \\
\text { as transformational, avoidant, and } \\
\text { transactional. }\end{array}$ & $\begin{array}{l}\text { Both in private and public universities } \\
\text { practiced transformational and passive } \\
\text { or avoidant leadership style. However } \\
\text { the transactional model was strongly } \\
\text { experienced by faculty members at the } \\
\text { private compared to the public } \\
\text { universities. }\end{array}$ \\
\hline 3 & $\begin{array}{l}\text { Bland et.al., } \\
1999 .\end{array}$ & $\begin{array}{l}\text { Quantitative with survey } \\
\text { questionnaire, interview, and focus } \\
\text { groups in the U.S. }\end{array}$ & $\begin{array}{l}\text { Effective leadership through } \\
\text { collaborative leadership strategies. }\end{array}$ & $\begin{array}{l}\text { Research found the effective } \\
\text { leadership behaviors that had } \\
\text { significant effects on organizational } \\
\text { outcomes include being consistent as } \\
\text { a leader, using various cognitive } \\
\text { approaches in empowering people, } \\
\text { employing a range of leadership styles } \\
\text { or behaviors specifically using the } \\
\text { participative approach and influencing } \\
\text { organizational culture, and } \\
\text { representing institutions in the } \\
\text { community membership or } \\
\text { partnerships. } \\
\text { Further, the study indicated that the } \\
\text { key leader role had more impacts on } \\
\text { outcomes compared with a leadership } \\
\text { team. }\end{array}$ \\
\hline 4 & $\begin{array}{l}\text { Anyamele, } \\
2005 .\end{array}$ & $\begin{array}{l}\text { EFQM (European Foundation for } \\
\text { Quality Management) as a theoretical } \\
\text { base model were used involving } \\
\text { academic leaders of the universities } \\
\text { In Finlandia. } \\
\text { Data were collected through } \\
\text { questionnaire s and interviews. }\end{array}$ & $\begin{array}{l}\text { University management approaches in } \\
\text { improving the quality. }\end{array}$ & $\begin{array}{l}\text { Various approaches were found to be } \\
\text { practiced in the quality improvement } \\
\text { programs in university management. } \\
\text { However, the success of university } \\
\text { was significantly influenced by the } \\
\text { implementation of the quality control } \\
\text { and leadership strategies. }\end{array}$ \\
\hline 5 & $\begin{array}{l}\text { Ali, et. al., } \\
2013 .\end{array}$ & $\begin{array}{l}\text { A quantitative study } 60 \text { instructors of } \\
\text { the universities in Mogadishu. }\end{array}$ & Leadership and job satisfaction & $\begin{array}{l}\text { A significant relationship was found } \\
\text { between transformational leadership } \\
\text { model and job satisfaction. }\end{array}$ \\
\hline 6 & $\begin{array}{l}\text { Asmawi, et.al., } \\
2013\end{array}$ & $\begin{array}{l}\text { Quantitative study } \\
\text { In Malaysia }\end{array}$ & $\begin{array}{l}\text { Leadership style and organizational } \\
\text { university culture }\end{array}$ & $\begin{array}{l}\text { Transformational leadership correlates } \\
\text { positively with R\&D culture in terms } \\
\text { of the variables: risk taking, tolerance, } \\
\text { share of knowledge, diversity, } \\
\text { participation, autonomy, social } \\
\text { network, and open communication. }\end{array}$ \\
\hline 7 & $\begin{array}{l}\text { Awan, } \\
\text { Mahmood, \& } \\
\text { Idrees, 2014. }\end{array}$ & $\begin{array}{l}\text { Quantitative approach employing } \\
\text { multi-variate statistics as well as t- } \\
\text { test, Chi-square, and ANOVA. } \\
\text { Questionnaires were administered to } \\
115 \text { employees as respondents of the } \\
\text { private universities' library in } \\
\text { Pakistan. }\end{array}$ & $\begin{array}{l}\text { Leadership, } \\
\text { organizational culture, and employee } \\
\text { commitment. }\end{array}$ & $\begin{array}{l}\text { No significant relationship was found } \\
\text { between leadership style and } \\
\text { organizational culture in public } \\
\text { universities. While at the private } \\
\text { university sector, libraries, showed } \\
\text { there is significant relationship } \\
\text { between leadership and organizational } \\
\text { cultures. } \\
\text { Further, it was not found a } \\
\text { relationship between the leadership } \\
\text { style and commitment of the } \\
\text { employees at both public and private } \\
\text { university libraries. } \\
\text { However, at both university types, } \\
\text { organizational culture was found to } \\
\text { have a significant relationship with } \\
\text { employee commitment. }\end{array}$ \\
\hline 8 & $\begin{array}{l}\text { Spendlove, } \\
2007 .\end{array}$ & $\begin{array}{l}\text { Qualitative approach employing } \\
\text { interviews involving Pro-Vice } \\
\text { Chancellors at ten universities in the } \\
\text { UK. }\end{array}$ & $\begin{array}{l}\text { Competencies of the executives and } \\
\text { leadership effectiveness. }\end{array}$ & $\begin{array}{l}\text { Leaders whose academic reputation } \\
\text { and experiences of the university } \\
\text { context were found crucial for the } \\
\text { effectiveness of leadership at higher } \\
\text { education institutions. This includes }\end{array}$ \\
\hline
\end{tabular}




\begin{tabular}{|c|c|c|c|c|}
\hline No & Sources & $\begin{array}{l}\text { Method / Research Design / } \\
\text { Technique }\end{array}$ & Variable / Subvariable & Findings: Leadership Behaviors \\
\hline & & & & $\begin{array}{l}\text { the capacities in conducting research } \\
\text { and teaching. } \\
\text { Additionally, communication skills of } \\
\text { the leaders were also to be perceived } \\
\text { by the sample as important. }\end{array}$ \\
\hline 9 & $\begin{array}{l}\text { Müller \& } \\
\text { Turner, } 2010 .\end{array}$ & $\begin{array}{l}\text { Quantitative approach using ANOVA } \\
\text { to identify differences in } \\
\text { competencies for project managers as } \\
\text { respondents. } \\
\text { Studies involved } 400 \text { participants } \\
\text { from } \\
\text { UK, Ireland, Australia, New Zealand, } \\
\text { the US and Canada. }\end{array}$ & leadership competencies & $\begin{array}{l}\text { Leadership competencies of the } \\
\text { project managers differ in developing } \\
\text { organizations to be successful. } \\
\text { Competencies in the dimensions of } \\
\text { critical thinking, influencing, } \\
\text { motivation, and conscientiousness are } \\
\text { perceived consistently with high } \\
\text { values by the successful projects' } \\
\text { managers. However, the other } \\
\text { competencies such as emotional } \\
\text { resilience, intuitive, and self } \\
\text { awareness are assessed differently } \\
\text { through the project types. }\end{array}$ \\
\hline 10 & Bolton, 1996 & $\begin{array}{l}\text { Quality approach with in-depth } \\
\text { interviews involving the deans of } \\
\text { School of Business in US and } \\
\text { European Universities. }\end{array}$ & $\begin{array}{l}\text { Leadership capacities of school } \\
\text { leaders. }\end{array}$ & $\begin{array}{l}\text { Despite experience under the pressure } \\
\text { concerning the demands of leadership } \\
\text { and management capacities, morale } \\
\text { dimension was regarded as the most } \\
\text { important factor in pursuing the } \\
\text { effective leadership in the university } \\
\text { organizations. }\end{array}$ \\
\hline 11 & Heuer, 2003 & Qualitative study in the U.S. & $\begin{array}{l}\text { Leadership in improving } \\
\text { organizational performance }\end{array}$ & $\begin{array}{l}\text { Successful organizations are } \\
\text { characterized by the strong leadership } \\
\text { on the top in most organizations or } \\
\text { companies. } \\
\text { Leaders who value human resources } \\
\text { have a positive impact on } \\
\text { organizational performance of the } \\
\text { university. }\end{array}$ \\
\hline 12 & Warwick, 2014 & Literature review & International strategy development & $\begin{array}{l}\text { Some universities in UK need } \\
\text { improve strategies in international } \\
\text { management. }\end{array}$ \\
\hline 13 & $\begin{array}{l}\text { Morris \& } \\
\text { Laipple, } 2015\end{array}$ & $\begin{array}{l}\text { Quantitative approach involving } 1515 \\
\text { university administrators in the US. }\end{array}$ & $\begin{array}{l}\text { Leadership skills, administrative roles } \\
\text { and job satisfaction. }\end{array}$ & $\begin{array}{l}\text { Wellness staff behavior are increased } \\
\text { effectively through the development } \\
\text { of leadership capacities of school or } \\
\text { university executives as well as the } \\
\text { well-established working systems for } \\
\text { the leaders to perform their tasks. }\end{array}$ \\
\hline
\end{tabular}

Sadeghi and Pihie (2012) found that universities in Malaysia have a combination of leadership styles including transformational, laissez-faire, and transactional [21]. Transformational is described as leadership behaviours working with people to detect organizational changes, create a vision as a direction to manage changes by motivations, and executing the changes with committed participants. While transactional leadership is a way of leaders to promote the performance of the followers using rewards and punishments. On the other hand, laissez-faire is explained as a style that allows members use their own initiatives without controlling the progress of the units. The implementation of the three styles was found as effective in managing university organizations. Analysis using a multiple regression reveals leader attributes as well as, motivation, reward, members' consideration, laissez-faire style, management, and intellectual encouragement - serve as significant predictors of this successful leadership behaviour within the university structure.

Effects of the transformational model is also found in studies reported by Ali et. al., 2013 that this leadership style significantly influenced job satisfaction of staff members working at universities in Mogadishu, Somalia [22]. Studies by Asmawi et.al, (2013) indicated that this style influenced significantly the improvement of research and development culture of the universities in Malaysia [23].

Furthermore, Bodla and Nawaz (2010) found universities in Pakistan used transformational and passive or avoidant leadership style. The evidence, however, indicates faculty members from private universities experienced more transactional model compared to the public universities [24]. In responding to this finding, universities are recommended to develop policies in improving leadership effectiveness ensuring capacities of the executives to manage the impending changes. In addition to the four leadership styles as highlighted in this section, participative behaviour was identified by Bland et.al. (1999) as an effective approach in leading workforces in university context [25]. This leadership style is predicted to have significant effects on the empowerment of people in building positive organizational and enhancing organizational outcomes of the universities. Such an approach is performed through a collaborative leadership strategy where leaders and the followers 
work together in pursuing the excellent or success of university organization. They also identified some essential leadership attributes that were found as effective in managing people at work including being consistent as a leader, using various cognitive approaches in empowering people, employing a range of leadership styles, building and improving organizational culture, and representing universities in the community membership.

On the other hand, studies by Muhammad Rafiq Awan, Khalid Mahmood, and Haroon Idrees (2014) indicated that leadership styles had no significant direct effects on organizational culture in public universities in Malaysia [26]. While at the private university sector, libraries, showed there is significant relationship between leadership and organizational cultures. Further, it was not found a relationship between the leadership style and commitment of the employees at both public and private university libraries. However, at both university types, organizational culture was found to have a significant relationship with employee commitment.

Focusing on the leadership competencies, Müller, Ralf, and Turner (2010) reported their studies that involved respondents from several countries: UK, Ireland, Australia, New Zealand, the US and Canada [27]. Results indicated that competencies in the dimensions of critical thinking, influencing, motivation, and conscientiousness are perceived consistently with high values by the successful projects' managers. However, the other competencies such as emotional resilience, intuitive, and self awareness are assessed differently through the project types.

Studies conducted by Spendlove (2007) in UK found that leaders whose academic reputation and experiences of the university context were found crucial for the effectiveness of leadership at higher education institutions [28, 29]. These include capacities in conducting research and teaching. Communication skills were also perceived as important. However, the leadership competencies of the project managers differ in developing organizations to be successful. This means that the mastery of skill varied among leaders. Specifically, studies conducted by Morris and Laipple, 2015 in U.S. showed that the wellness of staff behaviour are increased effectively through the development of leadership capacities of school or university executives as well as the well-established working systems for the leaders to perform their tasks [30]. With regard to those capacities, for the survival of the university organizations in the U.K., the findings of Warwick (2014) indicated that international strategic capacities were identified by most universities as important elements in improving their performance in the global competition in the future [31].

On the other hand, studies by Bolton (1996) in U.S. show despite experience under the pressure concerning the demands of leadership and management capacities, morale dimension was regarded as the most important factor in pursuing the effective leadership in many U.S. and European universities [32]. Almost relevant with the findings from studies by Heuer
(2003) in Pennsylvania, U.S.A that successful organizations are characterized by the strong leadership on the top in most organizations or companies [33]. Leaders who value human resources have a positive impact on organizational performance of the university.

\section{DISCUSSION AND CONCLUSIONS}

Based on several of finding resources this study recorded a range of leadership styles including transformational, transactional, and laissez-faire were applied in higher education institutions. The three styles were found effective in managing many university organizations. However, in general the findings indicated transformational model has dominantly characterized leadership behaviours of universities in many countries. This trend is consistent with previous studies $[11,21,27]$ that found effective leadership under the transformational model [34]. To ensure the effective leadership in influencing people at work, leaders propose a vision, initiate the changes through encouraging the followers to execute the programs in pursuing the vision enthusiastically, and with high commitment $[9,11,13]$. Such an expectation can be fulfilled through transformational process in influencing people at work.

On the other hand, the significant effects of participative leadership behaviours are relevant with some previous studies [5]. The use of single power as a leader was no longer relevant with the dynamic organizational contexts. This finding is in line with the nature of team leadership strategies which are probably required with the intent to establish a coalition in organizations. However, the effects of primary leader behaviours on the project success are stronger compared to this team strategy [25].

Surprisingly, no significant relationship was found between leadership style and organizational culture in public universities. But private university sector there were significant effects. The variations of the findings are consistent with theories suggesting part of the effects of leadership are determined by situational factors [11] that potentially moderate the impacts of leadership on organizational performance. Hence, leadership styles implemented by the executives only have direct impacts on employees' commitment which result in fostering the employees' performance.

Multi-variate statistics applied in the studies recorded key attributes which contribute to the success of university leadership. This includes motivation, reward, members' consideration, management, and intellectual encouragement constitute as the most important leader attributes which serve as significant predictors. Critical thinking, influencing, motivation, and conscientiousness, emotional resilience, intuitive, and self-awareness are also perceived as important capacities must be owned by university leaders. The findings are in line with leadership competence profiles identified by Dulewicz and Higgs [35]. Leadership styles highlighted in this study were developed in referring to what were proposed by Dulewicz and Higgs (2005) concerning people empowerment within strongly transformational situations. University 
organizations form particular or specific environments for the community where the leadership practice will be contingent with factors existing within the university system. The way how to lead an effective university, thus, differs to the styles applied in common organizations $[4,9,10]$.

In conclusion, higher education efforts in enhancing the nations building programs are implemented though providing universities with the vision to gain "excellence" in a global competitive environment. This condition requires a strong leadership that is able to inspire human resources contributing to the improvement of universities enthusiastically. transformational leadership was found as the right model in delivering such a condition.

However, contextually the effectiveness of university leadership depends on many factors. Leaders, thus, must consider the factors that could influence organizational climate within the university structures. They need to be familiar with the new trends and changes that challenge their position. Further, the executives of these sort education enterprises must have reputable competencies in building universities as the centre of scientific research and developments. These include high-valued morale, critical thinking, influencing followers, motivating people, consistent leader, conscientiousness, emotional resilience, intuitive, self-confidence, enthusiasm, and self-awareness. Such elements are vital in providing strong leaders for the enduring and successful universities in the future.

\section{REFERENCES}

[1] Lee, M.N.N. and S. Healy, Higher education in SouthEast Asia: an overview, in Higher education in SouthEast Asia. 2006, UNESCO: Bangkok.

[2] Tremblay, K., D. Lalancette, and D. Roseveare, Assessment of Higher Education Learning Outcomes. AHELO FEASIBILITY STUDY REPORT. Vol. 1 2012: OECD.

[3] Marginson, S., Dynamics of national and global competition in higher education. Higher Education, 2006. 52: p. 1-39.

[4] Jones, S., et al., Distributed leadership: A collaborative framework for academics, executives and professionals in higher education. Journal of Higher Education Policy and Management, 2012. 34(1): p. 67-78.

[5] Burhanuddin, Participative management and its relationships with employee performance behaviour: A study in the university sector in Malang Indonesia. 2013, The University of Adelaide: Adelaide, Australia.

[6] Holland, D., et al., The relationship between graduates and economic growth across countries. 2013: National Institute of Economic and Social Research.

[7] Gillis, M., Governance, in Higher education in developing countries: peril and promise. 2000, The World Bank: Washington DC.

[8] Marginson, S. and E. Sawir, University leaders' strategies in the global environment: A comparative study of Universitas Indonesia and the Australian National University. Higher Education, 2006. 52: p. 343-373.

[9] Bryman, A., Effective leadership in higher education: A literature review. Studies in Higher Education, 2007. 32(6): p. 693-710.
[10] Bolden, R., et al. Leadership in higher education: Facts, fictions and futures - introduction to the special issue. Leadership, 2009. 5, 291-298 DOI: 10.1177/1742715009337761.

[11] Yukl, G., Leadership in organizations. 2010, Prentice Hall: Upper Saddle River, New Jersey

[12] Zigarmi, P. and J. Hoekstra, Leading change, in Leading at a higher level: Blanchard on leadership and creating high performing organizations, T. Moore, Editor. 2007, Pearson Prentice Hall: Upper Saddle River, New Jersey.

[13] Blanchard, K., Introduction: leading at a higher level, in Leading at a higher level, T. Moore, Editor. 2007, Pearson Prentice Hall: Upper Saddle River, New Jersey.

[14] McKee, A., T. Kemp, and G. Spence, Management: a focus on leaders. 2013, Frenchs Forest, N.S.W.: Pearson.

[15] Blanchard, K., et al., Situational leadership II: The integrating concept, in Leading at a higher level: Blanchard on leadership and creating high performing organizations, T. Moore, Editor. 2007, Pearson Prentice Hall: Upper Saddle River, New Jersey.

[16] Reinhartz, J. and D.M. Beach, Educational leadership: Changing schools, changing roles. 2004, Boston: Pearson.

[17] Brick, J., Academic culture: A student's guide to studying at university. 2009, South Yarra: Macmillan.

[18] Burhanuddin, Leading the university to build a greater performance. KnE Social Sciences, 2017. 2017: p. 4659.

[19] Oxford, U.o. What is a meta-analysis? Centre for evidence based intervention (CEBI) 2017.

[20] Anyamele, S.C., Implementing Quality Management in the University: The Role of Leadership in Finnish Universities. Higher Education in Europe, 2005. 30(34): p. 357-369.

[21] Sadeghi, A. and Z.A.L. Pihie, Transformational Leadership and Its Predictive Effects on Leadership Effectiveness International Journal of Business and Social Science, 2012. 3(7).

[22] Ali, A.Y.S., M.A. Sidow, and H.S. Guleid, Leadership styles and job satisfaction: empirical evidence from Mogadishu universities. European Journal of Management Sciences and Economics, 2013. 1(1): p. 110.

[23] Asmawi, A., S. Zakaria, and C. Chin Wei, Understanding transformational leadership and $R \& D$ culture in Malaysian universities. Innovation, 2013. 15(3): p. 287-304.

[24] Bodla, M.A. and M.M. Nawaz, Comparative Study of Full Range Leadership Model among Faculty Members in Public and Private Sector Higher Education Institutes and Universities.

[25] Bland, C.J., et al., Leadership behaviors for successful university-community collaboration to change curricula. Academic Medicine, 1999. 74(11).

[26] Awan, M.R., K. Mahmood, and H. Idrees, Leadership Style, Culture and Commitment: An Analytical Study of University Libraries in Pakistan, in Library Philosophy and Practice. 2014, Libraries at University of Nebraska-Lincoln.

[27] Müller, R. and R. Turner, Leadership competency profiles of successful project managers. International Journal of Project Management, 2010. 28(5): p. 437448.

[28] Elliott, S.N. and M. Clifford, Principal assessment: leadership behaviors known to influence schools and the learning of all students (Document No. LS-5), in American Institutes for Research. September 2014, The 
Cedar Center University of Florida: Gainesville, FL 32611.

[29] Spendlove, M., Competencies for effective leadership in higher education. International Journal of Educational Management, 2007. 21 (5): p. 407-417.

[30] Morris, T.L. and J.S. Laipple, How prepared are academic administrators? Leadership and job satisfaction within US research universities. Journal of Higher Education Policy and Management 2015. 37(2).

[31] Warwick, P., The international business of higher education a managerial perspective on the internationalisation of UK universities. International Journal of Management Education 2014 12(2): p. 91103.

[32] Bolton, A., The leadership challenge in universities: The case of business schools. Higher Education, 1996. 31: p. 491-506.

[33] Heuer, J.J., Succession planning for key administrators at Ivy-Plus universities. 2003, University of Pennsylvania: Pennsylvania.

[34] Avolio, B.J., et al., Transformational leadership and organizational commitment: mediating role of psychological empowerment and moderating role of structural distance. Journal of Organizational Behavior, 2004. 25: p. 951-968.

[35] Dulewicz, V. and M.J. Higgs, Assessing leadership styles and organizational context. Journal of Managerial Psychology 2005. 20: p. 105-123. 